\title{
THE MARINE ELEMENT IN THE FAUNA OF THE GANGES
}

BY

\author{
N, A N N A N D A L E, D.Sc., \\ Director, Zoological Survey of India (Indian Museum, Calcutta).
}

In choosing a subject for my contribution to this volume I have been influenced by the value of Prof. MAX WEBER's investigations in the rivers and estuaries of Sumatra, Java and other Malayan islands $\left.{ }^{1}\right)$. We, who devote ourselves to a study of the fauna of Southern Asia, are deeply indebted to Prof. WEBER, not only for his own original researches and for his editorial work on the 'Siboga' reports, etc., but also for his fruitful travels in the Malay Archipelago. His liberality in the distribution of specimens has placed the members of my own department, the Zoological Survey of India, under special obligations in their examination of the fauna of fresh and brackish water in the Oriental Region.

In the preparation of this paper I have had to thank my friend and colleague Dr. STANLEY KEMP for many valuable suggestions.

\section{INTRODUCTION}

In discussing the aquatic fauna of Europe we are accustomed to divide it into two sections, the marine fauna and that of fresh water. With a few exceptions, such as that of the Decapod Crustacean Palaemonetes varians in brackish water in Northern Europe (and in fresh water in the Mediterranean region) and of certain molluscs found in the estuaries of all our large rivers, the separation between these two elements is fairly constant, and when marine species such as Mysis relicta are found in inland lakes the facts are considered exceptional. In tropical waters, however, conditions are different and we find not only a fairly large fauna of brackish water which cannot be regarded either as strictly marine or as strictly fluviatile, but also a considerable number of marine types that have established themselves permanently in fresh water far above the influence of the tides.

Among the problems that confront the biologist and the student of zoogeography few have greater interest than that of the origin of freshwater faunas, or rather of the fresh water fauna. For over the greater part of the world the animals that inhabit rivers and lakes have a great similarity and, indeed, include a large element of cosmopolitan genera and even species. This cosmopolitan element is of ancient origin. In India it can be traced back to the late Cretaceous beds of the InterTrappean period, in which species of such cosmopolitan molluscan genera as Limnaea, Vivipara and Corbicula occur in abundance. In other countries its known range in time is very much greater ${ }^{2}$ ), and the fact that even in the Inter-Trappean beds certain species already exist that are very closely allied to living forms from the swamps and pools of the same districts, proves that when these beds were deposited the genera had already been long established and had attained a high degree of stability

1) See his Zool. Ergbn. Reise Niederl. Ost-Ind. (Leiden, 1890-1897).

2) See Sollas on the origin of freshwater faunas in Trans. Roy. Dublin. Soç. (ii.) III (1884) and The Origin of the Earth (London, 1905). 
I may cite as examples the Inter-Trappean Limnaea oviformis ${ }^{1}$ ), Vivipara normalis ${ }^{2}$ ) and Lamellidens vredenburgi ${ }^{3}$ ), and their modern representatives ${ }^{4}$ ) Limnaea luteola Lamarck, Vivipara dissimilis (Müller) and Lamellidens marginalis (Lamarck). In each pair of species the resemblance is so close, so far as can be judged from the shells alone, that the living mollusc appears to be hardly more than a variety or race of its deceased ancestor. And yet the Inter-Trappean forms were contemporaneous with Dinosaurs ${ }^{5}$ ) and possibly even enterred into their diet.

We have in this paper to study a much more recent element in a fluviatile and estuarine fauna. The facts throw an interesting light on general problems, but this comparatively recent element cannot be regarded as genetically related to that which immigrated inland from the sea at a much earlier period and is now cosmopolitan in range.

It is well known that animals of marine origin inhabit the rivers of South America, Australia and China, but more attention has been devoted to the study of such forms in situ in British India than elsewhere in the Tropics. Well over a century ago the investigation was initiated by BUCHANAN, who later changed his name to Hamilton. His Fishes of the Ganges was published in London in 1822 as a result of the observations made by him when surveying Bengal in previous years. Later, much work was done by StoliczKa ${ }^{6}$ ), Blanford ${ }^{7}$ ), ANDERSON ${ }^{8}$ ), Nevill ${ }^{9}$ ), AlCocK ${ }^{10}$ ) and others. The general bearing of their discoveries has been discussed in reference to the origin of the freshwater fauna most fully by PeLSENEer ${ }^{11}$ ), while in quite recent years much additional information has been obtained by the officers of the Indian Museum and the Zoological Survey of India ${ }^{12}$ ).

\section{THE RIVER GANGES}

From the standpoint of our enquiry the origin, history and present course of the Ganges are of great importance. The valleys of northern India immediately south of the Himalayan ranges are occupied by the systems of three great rivers, the Brahmaputra to the East, the Ganges in the middle and the Indus to the West. These three rivers, at any rate in their present course, are approximately contemporaneous in origin and cannot have arisen earlier than the middle part of the Tertiary epoch ${ }^{13}$ ). Attempts ${ }^{14}$ ) have been made recently to prove on geological and faunistic evidence that the Indus and the Brahmaputra have a common origin and were once united, but an insuperable objection lies in the existence of high ground, in which there is no evidence of recent elevation, between them. The Ganges and the Brahmaputra are now so intimately connected that they may be said to form a single river-system, and even in the last two centuries there have been important interchanges between their

1) HISLOP, Quart. Journ. Geol. Soc. London XVI, p. 179, pl. V, fig. 18 (1860).

2) Hislop, Quart. Journ. Geol. Soc. London XVI, p. 166, pl. V, figs. $2 a, 2 b$ (1860) and ANNANDALE, Rec. Geol. Surv. Ind., LI, p. 363 (1921).

3) Baini Prashad, Rec. Geol. Surv. Ind. LI, p. 368, pl. XII, figg. 1. 2 (1921).

4) For figures of the recent shells see HANLEX and THEOBaLD. Conchologia Indica, pl. LXX, figs. 5, 6; pl. LXXVII, figs. 3 , 4, and pl. XLII, fig. 7 , etc.

5) MATLEY, Rec. Geol. Surv. Ind. LIII, p. 142 (1921).

6) StoliczKa on Polyzoa and an Actinian, in Journ. As. Soc. Bengal (ii.) XXXVIII (1869).

7) BLANFORD on the deltaic molluscs of the Irrawadi with many references to those of the Ganges, in Journ. As. Soc. Bengal (ii.) XXXVI (1867).

8) ANDERSON on Indian river-dolphins in his Anatomical and Zoological Results of his two journeys to Yunnan (1878).

9) NEvilL on Indo-Malayan molluscs in Journ. As. Soc. Bengal (ii.) XLIX, p. 159 and L, p. 125 (1880 \& 1881) and in Hand List of the Mollusca in the Indian Museum I \& II (Calcutta 1878 \& 1885).

10) Alcock on the crabs in Journ. As. Soc. Bengal (ii.) $1895 \& 1900$.

11) PELSENeER on the origin of freshwater animals in Bull. de l'Acad. Roy. de Belgique (Classe des Sciences), No. 12 (1905).

12) See in particular the Introduction to my volume on the freshwater Sponges, Hydroids and Polyzoa in the Fauna of British India series (London, 1911); the series of papers by various authors on the fauna of brackish pools at Port Canning in Rec. Ind. Mus., I and II (1907-1908) and the report on the fauna of the Chilka LaKe constituting Mem. Ind. Mus. V (1915 to date).

13) See MedlicotT and Blanford's Manual of the Geology of India (Calcutta, 1879): also Suess, The Face of the Earth (English edition) I, p. 387 (1904).

14) See PILGRIM, Journ. As. Soc. Bengal (n. s.) XV, p. 86 (1919) and PASCOE, Quart. Journ. Geol. Soc. London, LXXV, p. 138 (1920). In forming my own views I have been much indebted to personal discussions with my friends Mr. E. VREDENBURG and Mr. G. H. TIPPER of the Geological Survey of India. 
respective affluents. The Indus arises, like the Ganges, in the Himalayas and at no great distance from it, but flows in the opposite direction. That the connection between the Ganges and the Brahmaputra, which is an important river before it enters the Himalayas from the North, is comparatively recent there can be little doubt. The latter river, indeed, seems to have cut its southward channel through the great mountain mass on the confines of $\mathrm{W}$. China at a comparatively late date in its history and formerly to have pursued an easterly or south-easterly course.

One of the strongest arguments in favour of a direct connection between the Ganges and the Indus has always been the faunistic affinities of the two rivers, to which the range of the freshwater Cetacean Platanista gangetica and also that of most of the aquatic Chelonia ${ }^{1}$ ) is common. The argument is strengthened by the facts that Platanista does not occur in the Mahanaddi, the next important river to enter the Bay of Bengal from Peninsular India to the south of the Ganges, and that the Mahanaddi races of several aquatic Chelonia (e.g. Trionyx gangeticus, and Kachuga tectum) are distinct from those common to the Indus and the Ganges.

But, however strong the faunistic argument may be, it does not, to my mind, make it necessary to postulate that the Indus and the Ganges were ever joined together as rivers. At the beginning of the Tertiary epoch the territory which is now Peninsular India, one of the oldest of existing landmasses, was separated from the rest of Asia by a comparatively broad strait, in which conditions were completely marine. With the elevation of the Himalayas the channel became narrower, but probably was not completely obliterated. The streams that flowed down the southern slopes of the new mountain range must have brought with them much alluvium, the accumulation of which at its base would tend to fill in the channel. That this process was uniform all across the continent is improbable, and we may picture the existence of great lagoons, the interrelations of which were constantly changing, while their bed is now completely buried beneath the alluvial deposits of more recent rivers. Such a history would have given ample opportunities for the migrations of the fauna now common to the Indus and the Ganges.

The course of the Ganges ${ }^{2}$ ) and its tributaries may be devided into three regions; viz. the Upper Waters, in which they still flow among the mountains; the Middle Reaches, in which the river pursues a sluggish and uniform course through a great alluvial plain, and the Deltaic Tract, in which it breaks up into innumerable effluents and creeks more or less directly under tidal influence.

The river issues in lat. $30^{\circ} 56^{\prime} 4^{\prime \prime} \mathrm{N}$., and long. $70^{\circ} 6^{\prime} 40^{\prime \prime} \mathrm{E}$., from an ice-cave in the western Himalayas at an altitude of 13800 feet above the sea-level. Its Upper Waters are comparatively short and it debouches on the plains near Hardwar. At Allahabad, 668 miles from its source, it receives its chief tributary, the Jumna. Its Middle Reaches have a length of 700-800 miles and its Deltaic Tract one of about 100 miles.

It is with these two regions that we are concerned here, for there is no evidence of the existence of a marine element in the highly specialized fauna of the Upper Waters ${ }^{3}$ ). The two regions differ from one another both physically and in biological conditions. We may say, roughly speaking, that the Middle Reaches lie beyond the limits of tidal influence and possess a fluviatile fauna in which the marine element, though evident, is small, while the Deltaic Tract is tidal, even in places where the water is practically fresh, and is inhabited mainly by animals of marine origin. There is, it is true, no definite geographical or faunistic boundary between the two regions, but the contrast between them is striking when the middle parts of each are compared.

The small marine association in the true fluviatile fauna of the river is now completely cut off from the sea near the upper limit of tidal waters. It may therefore be called the Relict Fauna of the Ganges.

The aquatic fauna of the delta on the other hand, although it includes many characteristic and peculiar genera and species, merges gradually into that of the upper parts of the Bay of Bengal. The transition from fresh to salt water in this region is extremely gradual and at any given point in the stream changes in salinity are frequent, not only in accordance with the seasons, but also on account of the

1) See Annandale on the aquatic Chelonia ot the Mahanaddi in Rec. Ind. Mus. VII, p. 151 (1912).

2) For a concise description of the Ganges see HunTER's Imperial Gazetteer of India IV (1885).

3) See AnNANDAle on the Batrachian larvae in Rec. Ind. Mus. VIII, p. 32 (1912) and on the Mollusca, ibid., XXII, p. 530 (1921); also Sunder Lal Hora on the Fish, ibid. XXII, p. 633 (1921) and XXIV, p. 31 (1922). 
tides and of occasional accidents such as sudden floods. The waters of the Bay of Bengal, owing to its confined area and to the great rivers that flow into it on both sides, are much less salt than those of the ocean. The specific gravity as far south as the coast of Orissa ${ }^{1}$ ) at a standard temperature of $15^{\circ} \mathrm{C}$. is as low in the dry season as 1.027 to 1.02825 , while the fall in the course of the Ganges, once it has left the mountains, is so slight that the flow is largely inhibited by the rise of the tide at considerable distances from the sea. Great masses of fresh water, practically undiluted, are not, therefore, thrust out on the surface of the sea as at the mouth of the Yangtse and the Amazon, or probably even of the Indus (in which the gradient is much steeper), but the river-water and the seawater are intimately commingled. Even at a point still higher up stream, over a hundred miles from the open sea, the pressure exercised by the rising tide strongly affects the fresh river-water.

I propose to refer to the aquatic fauna of the delta as the Euryhaline Fauna.

\section{THE RELICT FAUNA OF THE RIVER}

The number of species and genera of comparatively recent marine origin that flourish in the Middle Reaches of the Ganges and are now completely isolated from the sea is small but of great interest. It probably includes, strictly speaking, but four species, representing three genera now known neither in the Bay of Bengal nor elsewhere in a true marine environment. The three genera are Platanista (Cetacea), and Scaphula and Novaculina (Mollusca Pelecypoda).

Platanista gangetica ${ }^{2}$ ), the only known species of its genus, is a small Cetacean highly modified for life in extremely muddy water, with degenerate eyes and a sensitive elongate snout, but belonging to an ancient family. The genus is known only from the Indus and the Ganges and a few immediately adjacent rivers. Other genera of Platanistidae occur, however, in the Amazon and the Yangtse.

The two bivalve genera, Novaculina and Scaphula, belonging to the Solenidae and Arcadae respectively, have both a somewhat wider range. Scaphula ${ }^{3}$ ), of which two species, S. celox and $S$. deltae, are found in the Ganges, is known from the rivers of central India and Burma. A species, as yet undescribed, was recently found by myself in the Tale Sap ${ }^{4}$ ) on the East Coast of Peninsular Siam. The Gangetic species are indentical with those of the Irrawadi, the Mahanaddi and the Cane River in Bandelkhand. Those from Tenasserim and Siam are distinct. The genus is perhaps the most primitive of its family, the hinges of the shell having a much simpler character than that of other genera. Dr. Ekendranath GHosh, who has examined the genus anatomically, tells me that its soft parts have also a primitive structure.

Novaculina $^{5}$ ) has been found (in different species) in the Ganges, in the Andaman Islands and in Siam ${ }^{\circ}$ ). It also appears to be a primitive genus. Dr. EKENDRANATH GHosh has recently made it the type genus of a new subfamily, which he regards as the most primitive of those that constitute the Solenidae. The shell has not assumed the extreme form characteristic of the "razor-shells", while the musculature, etc. are correspondingly unmodified.

$$
\text { our }
$$

We may discuss here an Amphipod Crustacean which appears, with our present knowledge, to be completely isolated in the Ganges, although the known facts are so extraordinary that further information will probably prove them misleading. I refer to Ampelisca pusilla ${ }^{7}$ ) Sars, an Arctic marine species which has recently been discovered, without any possible doubt as to the true provenance, high up in the Middle Reaches of the Ganges. In Indian waters its only other known occurrence is in euryhaline conditions in the Chilka Lake on the East Coast of India. But there can be little doubt that it will also be found in the Bay of Bengal when the Amphipod fauna is more thoroughly inves-

1) AnNandale \& Kemp, Mem. Ind. Mus. V, p. 9 (1915).

2) For a full account of the anatomy of this river-dolphin see ANDERSon, Zool. Anat. Results Yunnan, pp. 417550, pl. XXV, etc. (1878). On the Platanistidae see MAX WEBER, Die Säugetiere, p. 579 (Jena, 1904) and WINGE, Smithsonian Misc. Coll. LXXII, No. 8 (1921). Millar (Smithsonian Misc. Coll. LXVIII, №. 9, 1918) has placed a river-dolphin from the Yangtse system in the Iniidae, which are united with the Platanistidae by most recent authors.

3) Benson. Proc. Zool. Soc. London, 1834, p. 91 and PReston, Faun. Brit. Ind., Freshw. Moll., p. 129 (London, 1915).

4) Annandale, Journ. Nat. Hist. Soc.. Siam II, p. 73 (1916).

5) BENSON, Glean. Science II, p. 63 (Calcutta, 1820) and GHOSH, Rec. Ind. Mus. XIX, p. 64 (1920).

6) MORLET, Journ. Conchyl. XXXVII, p. 198 (1889).

7) ChIlton, Rec. Ind. Mus. XIX, p. 79 (1920). 
tigated. Recent discoveries as to the geographical range of several Amphipods capable of living in fresh or brackish water would seem to show that what is known as to this group of animals has very little bearing on the general study of zoogeography ${ }^{1}$ ).

The fish of the Middle Reaches of the Ganges mostly belong to well-known freshwater families, but certain marine or estuarine sting-rays, Clupeids and Siluroids made their way up stream far beyond the delta. With the possible exception, however, of a species of Clupea $(C \text {. suhia })^{2}$ ), these fish may be classified as euryhaline. Another Clupeid (Hilsa ilisha), one of the best known edible fishes of the river, is indeed, a typical anadromous fish.

\section{THE EURYHALINE FAUNA OF THE DELTA}

This fauna is rich and varied, including members of practically all the macroscopic phyla except the Echinodermata ${ }^{3}$ ), which seem to be absent. Our knowledge is still far from complete, and the space at my disposal here would render a detailed account of even what we know impossible. I shall, therefore, attempt merely to give a brief synopsis of a few of the more important or interesting groups, to illustrate the relations of the fauna with that of the Middle Reaches of the river and to summarize, so far as is at present possible, the leading features of the association and the peculiarities of some of its constituents.

PORIFERA. The muddy creeks and estuaries of the Gangetic Delta afford few situations suitable for the growth of sponges, the canals and apertures of which are liable to be congested by the fine silt held in suspension in the water or deposited on the bottom. I know of but two species able to withstand the adverse conditions, and one of these (Spongilla alba) ${ }^{4}$ ) is a freshwater form which has acclimatized itself in brackish water. The other is the cosmopolitan parasite Cliona vastifica ${ }^{5}$ ), which is not uncommon in oyster-shells in the lower part of the delta. This sponge has shown itself tolerant of a low salinity not only on the Indian coasts but also in Europe. When the deltaic creeks are more fully explored, it is probable that species of Suberitidae ${ }^{0}$ ) will also be found, for this family has exhibited euryhaline tendencies not only in Indian lagoons but also in the Black Sea and elsewhere.

COELENTERATA. The Coelenterates ${ }^{7}$ ) are richly represented in this fauna and no less than. six genera (three of Hydrozoa and three of Actiniaria) occur in the Deltaic Tract that have not been found in pure sea-water.

The Hydrozoan genera are Dicyclocoryne ${ }^{8}$ ), Annulella ${ }^{9}$ ) and Asenathia $^{10}$ ), The two former are hydroids, and the last is a medusa, possibly the sexual generation of Annulella. Each genus is known as a single species. Dicyclocoryne filamentata, originally found in a pool of brackish water in the Gangetic Delta and since rediscovered in the Chilka Lake, is a typical member of the family Corynidae. Evidence has recently been obtained that its medusa when adult has branched tentacles like Cladonema. These probably enable it to crawl on soft mud. Annulella gemmata is a much more remarkable form, a solitary hydroid which possesses a great variety of means of reproduction, producing lateral buds, which break free from the parent, basal resting-buds encased in horny material and free medusae. It is possible that the form described under the name Asenathia piscatoris is the adult form of the medusa. Both hydroid and medusa have as yet been found only in the brackish waters of the delta.

The Actiniaria ${ }^{11}$ ) of the same association are equally remarkable. The three genera are Diadumene,

1) See, for example, Chilton's reports on the Crustacea Amphipoda of the Chilka Lake in Mem. Ind. Mus. V (1921).

2) CHAUdhuRI, Rec. Ind. Mus. VII, p. 437 (1912).

3) The only Echinoderm, so far as I know. which shows the slightest inclination to enter brackish water is the holothurian Hamplodactyla molpadioides, which is found at the mouths of the Ganges and at that of the Tale Sap in Siam.

4) CARTer, Joutn. Bomb. Asiat. Soc. III, p. 32 (1849) and Annandale, Mem. Ind. Mus. V, p. 25 (1915).

5) Topsent, Arch. Zool. expérim. (2) V bis, 76 (1888) and ANNANDALE, Mem. Ind. Mus. V, p. 34 (1915).

6) ANNANDAle, op. cit. pp. 35-52 (1915).

7) ANNANDALE, Mem. Asiat. Soc. Bengal VI, p. 103 (1917).

8) AnNandale, Rec. Ind. Mus. I, p. 139 (1907) and Mem. Ind. Mus. V, p. 110 (1915).

9) RitchiE, Rec. Ind. Mus. XI, p. 541. (1915).

10) AnNandale, Mem. Asiat. Soc. Bengal VI, p. 114 (1917).

11) See StoliczKa, Journ. Asiat. Soc. Bengal (ii.), XXXVIII, p. 28 (1869); AnNandale, Mem. Ind. Mus. V, pp. 68-102 (1915) and Mem. Asiat. Soc. Bengal VI, p. 103 (1917); STEPHEnSON; Quart. Journ. Micro. Sci. LXIV, pp. 520-523 (1920). 
Phytocoetes and Pelocoetes, each of which is known from a single species. Diadumene schilleriana, one of the earliest Actinians to be described anatomically in detail, is a fixed form which attaches itself to floating logs, etc. It is known only from the Gangetic and Irrawadi deltas and from water that is. nearly fresh. Phytocoetes gangeticus and Pelocoetes exul come from the same region but are burrowing forms with a vestigial basal disk and live buried in soft mud. $P$. exul occurs also in the Chilka Lake and in backwaters near Madras, but $P$. gangeticus has not been found elsewhere than in the Gangetic Delta. It is replaced in the Chilka Lake by an allied form ( $P$. chilkaeus), which has recently been placed in a distinct genus on account of a technical difference. STEPHENSON has grouped the three (or four) genera in a distinct family, the Diadumenidae, which he regards as in many respects primitive, representing the ancestral type of the Sagartiidae modified in certain directions. If this view should prove correct, we have in the Actiniaria of the Gangetic Delta an endemic family, the range of which; so far as is known, does not extend beyond the brackish waters of the East Coast of Peninsular India and of Burma.

Apart from peculiar genera, several other Coelenterates occur in the Deltaic Tract. The only one that need be mentioned here is the hydroid Bimeria fluminalis, one of the commonest constituents of the Euryhaline Fauna. It has been found not only in the Ganges, but also at the mouth of a small river in Orissa, in the Chilka Lake and in the Tale Sap, a somewhat similar lagoon that opens into the Gulf of Siam, always in water of low salinity and occasionally in water that was temporarily fresh. In the latter medium colonies produce their sessile gonophores in great profusion, while the vegetative parts degenerate rapidly. I shall have more to say later of another abundant hydroid (Campanulina ceylonensis) and its medusa.

As few Coelenterata are known to make their way into fresh or even brackish water in other regions, I may mention here two species of sea-anemones not yet found in the Ganges but living in euryhaline conditions in the Chilka Lake. They are Edwardsia tinctrix and Halianthus limnicola, both representing genera not yet discovered in the open sea, or in water of normal marine salinity, in Indian seas, though well known in those of the North and the South of both hemispheres.

POLYCHAETA. Our knowledge of the Polychaeta of the Ganges is still far from complete, but we know that Nereidae occur in pure fresh water at least as high up as the limits of tidal influence. Several peculiar species and genera belonging to different families have recently been described from a little lower down stream by Dr. SouTheRN ${ }^{1}$ ), while others, known to exist, are still undescribed. Three genera are at present known only from brackish water in the Gangetic Delta, viz. Barantolla and Dendronereides Southern, and Matla Stephenson ${ }^{2}$ ).

ECHIUROIDEA. This group is represented in the Gangetic delta by a curious form originally described by Dr. KeMP and myself ${ }^{3}$ ) as Thalassema gangetica. I now regard it as belonging to a new genus, for which I propose the name Anelassorhynchus ${ }^{4}$ ). In this genus the proboscis is of simpler structure and less contractile than in the other Echiuroidea. It is not so contractile as the body and cannot be cast off by autotomy. In most forms it bears processes apparently of a respiratory nature. Four species are now known, three of which live in brackish water, while the fourth is marine, or rather lives at the mouth of a small stream. All are found in Oriental waters and all inhabit soft mud. I regard them as perhaps the most primitive of the true Echiuroidea.

1) SOUTHERn, Mem. Ind. Mus. V, pp. 565-659 (1921).

2) StePhenson, Rec. Ind. Mus. II, p. 39 (1908) and Willey ibid. p. 389 (1909)

3) AnNandale \& Kemp, Mem. Ind. Mus. V, p. 56 (1915).

4) Anelassorhynchits gen. nov. The genus consists of Echiuroidea allied to Thalassema Gaertner, but differing in the structure, function and physiology of the proboscis. This organ is relatively stout and short, incapable of great prolongation or autotomy. The ciliated groove on its ventral surface is feebly developed and the lateral margins of the ventral surface bear (except in A. microrhynchus) gill-like outgrowths. The longitudinal muscle-fibres of the body form a single sheath and the musculature bears a close resemblance to that of some species of Thalassema. There are two pairs of nephridia. The anal funnels are simple and thin-walled; their ciliated funnels are minute.

The type-species is A. branchiorhynchus (Annandale \& Kemp). The other species are A. dendrorhynchus (Annandale \& Kemp), A. sabinum (Lanchester) and A. microrhynchus (Prashad). These species are discussed by PRASHAD in Mem. Asiat. Soc. Bengal VI, pp. 323-336 (1919) and Rec. Ind. Muts. XVI, pp. 399-402 (1919). He does not regard their peculiarities as of generic importance. 
MOLLUSCA. The molluscan fauna ${ }^{1}$ ) of the Gangetic Delta is very rich and, so far as the true aquatic species are concerned, still imperfectly known. Amphibious or practically terrestrial Gastropods belonging to the families Neritidae, Littorinidae, Assimineidae and Auriculidae occur in large numbers on the mud-flats exposed at low tide and even on the trunks of mangroves and on the upright mud roots of trees such as Avicennia. Many of these species are small and inconspicuous and at present are only known from the Ganges. (It is noteworthy, however, that Assiminea miniata ${ }^{2}$ ), which is conspicuous on account of its brilliant scarlet colour, is known to have a very wide range in Indo-Pacific estuaries). Some of the species are found in almost pure fresh water, for example the gorgeous Neritina smithii, which occurs on posts and tree-trunks at the edge of creeks as high upstream as Calcutta. Others are almost marine. Perhaps the most interesting of the members of this molluscan fauna is the enigmatic little Mainwairingia paludomoides, hitherto recorded only from the edge of creeks of brackish water in the Gangetic Delta but recently found in a backwater near Madras and also in the Rangoon River. It has hitherto been placed in the Melaniidae, but must now be associated with the heterogeneous assembly of genera provisionally named Rissoidae.

Of the known species of Gastropoda that live entirely submerged in the deltaic creeks the most characteristic belong to the genera Stenothyra, Iravadia, Nassa, Ringicula and Cuthona. Stenothyra ${ }^{3}$ ): a genus with numerous species in the estuaries of India, Malaysia and China, seems to be intermediate in structure between the families Hydrobiidae and Rissoidae, if these two families can be kept distinct. The affinities of Iravadia are unknown in the absence of all information as to the anatomy, but it probably belongs to one or other of the same families. Unlike Stenothyra, some species of which make their way well into the Middle Reaches of the river, Iravadia seems to be confined to brackish water. The marine genus $N a s s a^{4}$ ) is represented in the brackish waters of the Indian coasts by several species noteworthy for their small size, their thin shell and somewhat reduced radula. The common species in the delta is $N$. ennurensis.

The Opisthobranchiata are in general so characteristically marine that the occurence of species living in euryhaline conditions is particularly interesting. Several Nudibranchs ${ }^{5}$ ) are now known to inhabit the estuaries and lagoons of the Oriental Region just as Alderia inhabits ditches of brackish water in Europe. In the Gangetic Delta, the only euryhaline species yet discovered is Cuthona annandalei, found in water of much lower salinity even than that of the Bay of Bengal. The Tectibranchs are represented in the same region by a blind species of Ringicula $(R$. caeca), which lives on the soft mud of the bottom and differs from most of the submerged molluscs of brackish water in its extremely massive shell, which however, is very small.

Bivalve molluscs are less abundant in this fauna than Gastropods, but several species occur in large numbers and are characteristic. Those that are most so are perhaps Cyrena bengalensis ${ }^{\circ}$ ), Clementia annandalei ${ }^{7}$ ) and Modiola striatula ${ }^{8}$ ). The two first species belong to genera found mainly in brackish water but of wide geographical range in the tropics. They (belonging respectively to the families Cyrenidae and Veneridae) offer a remarkable contrast in the structure of their shells, for whereas in Clementia the valves are almost as thin as paper and extremely brittle, in Cyrena they are thick and stout. Both the species seem to have a limited range on the Indian coasts, the Cyrena being known only from Bengal and Burma and the Clementia (elsewhere) only from the Chilka Lake. Modiola striatula (family Mytilidae) belongs to a genus which in Western waters is distinctly

1) Benson, Ann. Mag. Nat. Hist. (iii.), I, p. 408 (1858); Blanford, Journ. Asiat. Soc. Bengal XXXVI, p. 51 (1867); Nevill, Journ. Asiat. Soc. Bengal XlIX, p. 159 (1880); Annandale \& KemP, Mem. Ind. Mus. V, p. 327 (1916); Hornell, Rec. Ind. Mus. XIII, p. 153 (1917); ANNANdale \& PRASHAD, Rec. Ind. Mus. XVI, p. 241 (1919).

2) This is not a Gangetic species, unless it be a mere colour-form of $A$. brevicula. BLANFORD's $A$. rubella is quite distinct.

3) Annandale \& Prashad, Rec. Ind. Mus. XXII, p. 136, pl. XVI (1921).

4) Preston, Rec. Ind. Mus. XII, p. 28, fig. 2 (1916); Annandale \& Prashad, ibid. XVI, p. 253, fig. 6, pl. XX, fig. 9 (1912).

5) Eliot, Rec. Ind. Mus. V, p. 248, pl. XIX (1910); Mem. Ind. Mus. V, p. 377 (1916); Mem. Asiat. Soc. Bengal

VI, (1916). Another species will be described shortly by Dr. BaINI PRASHAD and myself in Mem. Ind. Mus. V.

6) BaIni Prashad, Rec. Ind. Mus. XXII, p. 138, pl. XX, figs. 1, 2 (1921).

7) Preston, Rec. Ind. Mus. X, p. 306, fig. 14 (1914).

8) Annandale \& KeMP, Mem. Ind. Mus. V, p. 360 (1916). 
marine but in Southern Asia exhibits an increasing tendency to establish itself in fresh water as its range proceeds further East. In the Gangetic delta and in the Chilka Lake $M$. striatula occurs both in salt and in brackish, and occasionally even in fresh, water.

POLYZOA $^{1}$ ). Both the Entoprocta and the Ectoprocta are represented in the Euryhaline Fauna, the former by two and the latter by three genera. The most peculiar species is the Entoproct Loxosomatoides colonialis. It belongs to a genus endemic in brackish water on the coasts of India, but allied to another (Chitaspis) found only in the Tale Sap in Peninsular Siam. The only other species of the little group as yet discovered is L. laevis from the lagoons on the East Coast of India. L. colonialis has been found only in the Gangetic Delta in brackish water. A second Entoproct (Barentsia gracilis), usually of marine habitat and of wide geographical range, occurs in the delta in the Matla river.

Of the three genera of Ectoprocts two (Victorella and Bowerbankia) belong to the Ctenostomata and one (Membranipora) to the Cheilostomata. The Victorella ( $V$. bengalensis) is very closely allied to $V$. symbiotica, which inhabits brackish and fresh water in Europe. In Eastern Asia it is usually found in the former medium but it has been taken in freshwater pools near Calcutta. The Bowerbankia appears to be identical with $B$. caudata, a marine European species. Both $V$. bengalensis and $B$. caudata occur in the Tale Sap as well as in Indian waters. A Membranipora (M. hippopus) is also a European species of very wide geographical range, throughout which it frequents both salt and brackish water.

A second species ( $M$. bengalensis) is Oriental, having been found in the Ganges, et Bombay and in the Tale Sap.

XIPHOSURA. The King-Crabs are usually regarded as purely marine, but Carcinoscorpius rotundicauda, as I have observed ${ }^{2}$ ) both in the Malay Peninsula and in India, is usually estuarine in its habits. In the neighbourhood of Calcutta it has been taken occasionally in fresh water, both in ditches and in the Hugli.

CRUSTACEA. Our knowledge of the Crustacea of the Gangetic Delta concerns mainly the riparian and the free-swimming forms; as yet we know little about the true aquatic burrowing species, which are represented by several interesting forms in the Euryhaline Fauna of other Oriental waters. We know very little, moreover, of the Amphipoda and Isopoda of the creeks and mangrove-swamps.

The Entomostraca have been studied by GuRneY ${ }^{3}$ ) and by SEwELL ${ }^{4}$ ). The latter has shown that the estuarine Copepoda are liable to developmental polymorphism of a peculiar type.

Of the known Amphipoda I can here mention only Grandidierella megnae and Quadrivisio bengalensis ${ }^{5}$ ). These are among the most characteristic of the euryhaline Crustacea of Indian waters. The former is known from a salt lake in Madagascar and from various estuaries and lagoons on the coasts of India, while the latter has been found in the Tale Sap on the east coast of Peninsular Siam as well as in similar localities on the coast of India; also, in a blind phase, from underground waters in the island of Zanzibar. Both species can live in salt or brackish water and also, for a time at any rate, in normal fluviatile conditions.

Two species of Mysidacea $^{6}$ ) have a similar habitat in the Ganges and elsewhere on the Indian coasts. They are Potamomysis assimilis and Macropsis orientalis. The Potamomysis is of interest from a geographical point of view, for (like the medusa Asenathia) it is related to a form found in the Black Sea system.

The Crustacea Decapoda ${ }^{7}$ ) are well represented in this fauna. Among the Reptantia the charac-

1) Stoliczka, Journ. Asiat. Soc. Bengal XXVIII, p. 28 (1869); Annandale, Mem. Ind. Mus. V, p. 119 (1915) and Mem. Asiat. Soc. Bengal VI, p. 15 (1916). The genus Hislopia, which SToliczkA regarded as an ally of Membranipora is really a Ctenostome and belongs to a true fluviatile family. See AnNANDale, Faun. Brit. Ind., Freshwater Sponges, etc., pp. 190-199 (1911) and op. cit. pp. 33-37 (1916).

2) Annandale, Rec. Ind. Mus. III, p. 294 (1909).

3) GURNEY, Rec. Ind. Mus. II, p. 21 (1907).

4) SEWELl, Rec. Ind. Mus. VII, p. 313 (1912) and XVI, p. (1919).

5) Stebbing, Rec. Ind. Mus. I, p. 159 (1907) and II, p. 119 (1908); Chilton, Mem. Ind. Mus. V, pp. 537-549 (1921); TatTersall, Mem. Asiat. Soc. Bengal VII, p. (1922).

6) Tattèrsall, Rec. Ind. Mus. II, pp. 230-239 (1908); Mem. Ind. Mus. V, pp. 149-161 (1915); Rec. Ind. Mus. (ined.: 1922).

7) See Alcock, "Materials for a study of the Carcinological Fauna of India" in Journ. Asiat. Soc. Bengal 18951900; DE MAN, Rec. Ind. Mus. II, pp. 211-231 (1908); KeMP, Mem. Ind. Mus. V, pp. 201-325 (1915); Rec. Ind. Mus. XIII, pp. 243-279 (1917), XVI, pp. 305-349 (1919). 
teristic families are the Hymenosomatidae, the Ocypodidae; the Grapsidae and the Portunidae. The species of most of these families are burrowing marginal crabs; but the Hymenosomatidae live mainly submerged, while the Portunidae are swimming-crabs. The former family consists of minute unobtrusive species, many of which are probably still unknown. The recent work of Dr. STANLEY KeMP, however, has shown that numerous species are to be found among the Euryhaline Fauna of Indian estuaries. In New Zealand and in China Hymenosomatid crabs have established themselves in inland freshwater lakes, while in the Ganges one genus (Hymenicoides) is only known from fresh water within the limits of tidal influence.

The Portunidae are only noteworthy, so far as the Euryhaline Fauna is concerned, because they include the largest and one of the commonest of the Gangetic crabs: - Scylla serrata, the common edible crab in India, Malaya and Siam. It is found almost exclusively in brackish water.

The greater number of the euryhaline crabs belong to the family Grapsidae, and to such genera as Sesarma, Varuna, Grapsus and Ptychognathus. The commonest of all is Varuna litterata, of which I shall have more to say presently. Next to the Grapsidae in point of numbers come the Ocypodidae, most of which belong to the subfamily Scopimerinae. Some of the little crabs of this subfamily (notably Tympanomerus stapletoni, which is very common on the banks of the Hugli at Calcutta) might almost be reckoned among the Relict Fauna; but, although they are usually found in fresh water, their range does not as a rule extend inland beyond the delta.

Two families of the Natantia are conspicuous in the Euryhaline Fauna, namely the Penaeidae and the Palaemonidae 1). Several genera of the former occur in brackish water, but all appear to be catadromous, descending to the sea to breed and returning to the estuaries in a larval or postlarval stage. Among the Palaemonidae of the delta we find representatives both of the essentially freshwater genus Palaemon and of Leander, which is mainly marine. Leander occurs in this region in three species, L. styliferus, $L$. tenuipes and $L$. fluminicola. These three species are closely allied, but $L$. tenuipes is distinguished from the others by the extreme length and tenuity of its walking legs, which are no longer capable of supporting it on the bottom but have apparently assumed the function of tactile organs. This species and L. styliferus are anadromous, but do not migrate inland beyond the limits of brackish water. L. fluminicola on the other hand is equally at home in fresh and in brackish water and is common well above the upper extremity of the delta.

Few, if any, of the euryhaline Decapod Crustacea of the Ganges are strictly endemic in its waters. The majority of them, if not all, are found at any rate in the other estuaries that open into the Bay of Bengal.

FISHES. The rich fish-fauna of the Gangetic Delta ${ }^{2}$ ) was made known to systematic zoology a century ago by BuCHANAN and little of real importance has been added to our knowledge since. These fish fall into three categories: - (1) Anadromous species such as the Hilsa (Hilsa ilisha), a large herring of great economic value, which ascend the Indian rivers periodically to breed; (2) true euryhaline species able to endure the whole range of salinities from those of the Bay of Bengal to fresh water, but not exhibiting any marked periodicity in their migrations and (3) strictly estuarine species which live mainly in brackish water and rarely visit either the open sea or the Middle Reaches of the river ${ }^{3}$ ). Among these last are included numerous Siluridae, Clupeidae and Gobiidae. Perhaps the most remarkable are the gobies, which are represented by a great diversity of forms, such as the minute transparent fish ${ }^{4}$ ) allied to BLEEKER's Apocryptes brachypterus and the curious scarlet eel-like Taenioides rubicundus.

The most interesting of the strictly euryhaline species are the sting-rays ${ }^{5}$ ) Trygon fluviatilis and Hypolophus sephen, both of which occur both in the Bay of Bengal and in the Ganges hundreds of miles above the delta. They have both been found breeding in the sea and also in the river.

MAMMALIA. The only euryhaline mammal in the Gangetic fauna is the small Cetacean Orcaella

1) KEMP, Rec. Ind. Mus. XIII, pp. 203-231 (1917).

2) Buchanan, Fishes of the Ganges (London, 1822); DAY, Fishes of India (1876).

3) TAte Regan, Ann. Mag. Nat. Hist. XIX (8), p. 306 (1917).

4) These fish will shortly be described by Dr. Sunder Lal Hora in a new genus in Mem. Ind. Mus. V.

5) Chaudhuri, Journ. Asiat. Soc. Bengal (n. s.) VII, pp. 625-629 (1915). 
brevlrostris ${ }^{1}$ ), a marine species found in the river with Platanista gangetica, to which it offers a strange contrast in its short, rounded head. It is an actively predaceous animal common in the Bay of Bengal, the Gulf of Siam and neighbouring seas, but has been taken 900 miles up the Irrawadi. In the Ganges it does not ascend much above the delta.

\section{RELATIONS BETWEEN THE RELICT AND THE EURYHALINE FAUNAS}

As will be clear from what has been already said, the number of species of marine origin that have established themselves permanently in fresh water above the limits of tidal influence in the Ganges since the old immigration of the cosmopolitan freshwater fauna, is small. Most of these species belong, however, to genera no longer found in the sea and probably of relatively ancient origin. The marine fauna of the delta, on the other hand, is rich and includes not only many peculiar genera, but others, and even species, which also live in the sea. I cannot, however, find any definite dividing line between these two faunas. The relict fauna consists merely of organisms that have proved more capable of establishing themselves in abnormal circumstances and, therefore, more successful in the peculiar line of life adopted by them. A very slight change either in external circumstances or in the constitution of the organisms themselves would enable many other species to do likewise. Let me give two examples: that of the crab Varuna litterata ${ }^{2}$ ) and that of the Hydrozoon Campanula ceylonensis ${ }^{3}$ ), both species of wide geographical range in the open sea and in estuaries and lagoons.

Varuna litterata is in many parts of the Gangetic Delta one of the most abundant animals. It is found mainly in brackish water but has been taken clinging to floating logs far out at sea. In those parts of the delta that lie near the upper limits of direct tidal influence, the species appears in a late megalopa stage in enormous numbers every year about the beginning of the rainy season. The water of creeks and canals and of the quieter parts of the rivers is alive with them; they crowd into smaller water-channels and sometimes completely block up supply-pipes and drains, such as that which conveys water into the moat round Fort William in Calcutta. The great endeavour of the little Crustacea seems to be to make their way inland and to reach fresh water. At the same season or a little later the adults also migrate inland in large numbers, but mainly by land. The damp air and the flooded state of the drains and the gutters in the streets of Calcutta facilitate their progress. Every year a few make their way through the city to the pond in the garden of the Indian Museum, and individuals have been seen in adjacent gardens on dry land surrounded by a crowd of house-crows.

And yet, in spite of this annual attempt at immigration carried out on so vast a scale, the species has never succeeded in establishing itself in the Gangetic delta in water that is permanently fresh. Individuals apparently have no objection to fresh water and the factor that at present stands in the way of their aim is probably the competition of the already-established Potamonidae, against which they seem to be unable to hold their own.

My other instance is that of the Hydrozoon Campanulina ceylonensis ${ }^{4}$ ), a species of which the medusa was originally described from the sea but has since been found in brackish water in Siam as well as in India. Every year the lock-gates of a certain canal on the outskirts of Calcutta are opened about April and water flows in from creeks of brackish water in the delta. Shortly afterwards, the water, having at the time a specific gravity of about 1.0085 at $15^{\circ} \mathrm{C}$., becomes alive with the medusae of this Hydrozoon, while the minute hydroid is to be found on almost every submerged brick or pile in the canal. Both generations remain abundant until the rainy season commences in June or July. Then the specific gravity of the water sinks rapidly. As it does so the medusae and hydroids become scarcer. They finally disappear when it falls to about 1.0060 . The hydroid is an exceedingly delicate organism, but the medusa, in spite of a somewhat fragile appearance, is extraordinarily hardy. I have

1) For an account of the anatomy see ANDERson, Zool. Anat. Res. Yunnan, pp. 358-416 (1878). Recent authors regard ANDERSON's "Orcella fluminalis" as synonomous with O. brevirostris (Owen).

2) ALcock, A Naturalist in Indian Seas, p. 75 (London, 1902); Kemp, Mem. Ind. Mus. V, p. 233 (1915)

3) Browne on the Medusae in Herdman's Rep. Ceylon Pearl Fish. IV, pp. 140, 141 (1905); ANnandale, Rec. Ind. Mus. I, p. 142 (1907); Lloyd \& ANNANDale, Rec. Ind. Mus. XII, pp. 49-57 (1916); ANNANDale, Mem. Asiat. Soc. Bengal VI, p. $112(1917)$.

4) Lloyd \& Annandale, Rec. Ind. Mus. XII, p. 49 (1916); Annandale, Mem. As. Soc. Bengal VI, p. 112 (1919) 
carried about several individuals in a small corked tube of water in my waistcoat pocket for a whole day without their showing any signs of degenerating. After the eggs and spermatozoa are completely discharged, senility and finally death take place slowly, the organs degenerating gradually over a period of several days until practically nothing but the manubrium, which still exhibits languid movements, persists. The medusa, moreover, is unusually adaptive in its feeding. It can capture and devour small Crustacea in the ordinary manner, but it can also obtain nutriment by sucking out the contents of the cells of filamentous green algae.

In this species the inhibitive factor seems to be merely an incompletely developed adaptability to changes in salinity, or possibly rather specific gravity, in the water on the part of the animal itself.

My two instances should prove at any rate that the factors influencing the inland migration of marine forms are extremely diverse, and that each instance must be studied by itself.

\section{GENERAL CHARACTERS OF THE MARINE ELEMENT IN THE FAUNA OF THE GANGES}

Can we discover any peculiarities common to the diverse members of the marine element in the fauna of the Ganges? To answer this question satisfactorily, in our almost complete ignorance of the physiological changes involved in the transition from salt to fresh water is at present impossible. Certain negative characters of an indefinite but visible kind certainly exist, such as small size and general absence of brilliant or conspicuous colouration. Adaptations for life in muddy water such as degenerate eyes and highly developed tactile organs are common, while various kinds of resting-buds or other highly resistant non-sexual reproductive bodies are produced by certain species, just as they are produced by freshwater organisms. To cite a few examples; the species or Arcadae, Solenidae and Nassidae are smaller than most of their marine relatives, while very few of the Crustacea and none of the Coelenterata are even moderately large. The only bright colour commonly present is a pink or red that recalls that observed in deep-sea animals. This colour is found in the ornamentation of several of the euryhaline prawns such as Leander styliferus and generally diffused on the surface of a few of the fish, such as Taenioides rubicundus. The long sensitive snout of Platanista acts as a tactile organ and takes the place of its useless eyes; the filamentous legs of Leander styliferus, in which, however, the eyes are not degenerate, have a similar function, while the barbels of many purblind euryhaline Silurids and the elongate fin-rays of Polynemus paradiseus are even more closely analogous. Similarly the basal buds of the hydroid Annulella are analogous to the reproductive capitula of the Entoproctous Polyzoon Loxosomatoides ${ }^{1}$ ) or with the internal resting buds of the Ctenostome Victorella ${ }^{2}$ ).

Dr. Stanley KeMP $^{3}$ ) has observed an interesting phenomenon in the Euryhaline Fauna, and particularly in the fish and Crustacea, of certain creeks in the Gangetic delta, viz. the superficial resemblance between this fauna and that of the deep sea, particularly in colouration and in the existence of elongate tactile organs. His paper may be consulted for details, which I have not the space to discuss here. He correlates the phenomenon with two common factors in the two types of environment so dissimilar in most respects. These are low visibility and a very soft muddy bottom.

Among all the species belonging to the Euryhaline Fauna of Indian waters I know of but one instance that can be definitely correlated with life in a medium of reduced specific gravity. This lies in the structure of the larva ${ }^{4}$ ) of Laxosuberites lacustris, a sponge common in the Chilka Lake. The peculiarity of the larva is that it is hollow, almost like that of the freshwater Spongillidae or the analogous larvae of the Phylactolaematous Polyzoa.

\section{CONCLUSIONS}

From the facts stated above, and from others of like nature which there is not space to cite here, I adduce the following conclusions:

(1). The Bay of Bengal, with its low salinity and gradual changes from salt water to fresh is an

1) Annandale, Mem. Ind. Mus. V, pp. 129-132, figs. 2, 3 (1915).

2) HARMER, Proc. Zool. Soc. Lond. III, p. 441 (1913).

3) KeMP, Rec. Ind. Mus. XIII, pp. 233-241 (1917).

4) AnNandale, Mem. Ind. Mus. V, p. 48, fig. 11 (1915). 
exceptionally favourable starting-point for an immigration into fresh water on the part of marine organisms.

(2). An immigration of the kind has been in progress for a long period and many adaptable euryhaline species are still attempting to establish themselves above the limits of tidal influence in pure fresh water. A very slight change either in the environment or in the constitution of the animals themselves would enable them to do so.

(3). The Relict and Euryhaline Faunas of the Ganges represent different stages in this process of inland immigration. The process has been gradual, and there is little evidence that it originated in periodical anadromous journeys associated with reproduction. It seems rather to have proved successful owing to the vigorous constitution and physiological ambition of those organisms that have missed no accidental opportunity of establishing themselves in fresh water.

(4). A large proportion both of the euryhaline and of the relict forms are superficially adapted to their environment, but in only one species (the sponge Laxosuberites lacustris) can structural modification be correlated with changes in the chemical composition or specific gravity of the medium in which the animal lives. In this respect adaptation is usually physiological rather than anatomical. In most species anatomical adaptations are correlated with life in very soft mud or extremely muddy water such as are found in the bed and streams of a slow flowing silt-laden river. These conditions may even be correlated with a superficial resemblance between the fauna of deltaic creeks and the abyssal fauna of the ocean, the muddy water producing a low visibility comparable to that produced by the non-penetration of light in the depths of the sea, in which the bottom is usually a soft ooze.

(5). In spite of superficial changes, a large proportion of both the relict and the euryhaline forms are of essentially primitive structure, or at any rate belong to ancient groups, some of which have almost or completely disappeared from adjacent seas. In other words, fresh and brackish water have proved a last refuge for many marine animals whose race in the sea was nearly done.

(6). Such evidence as we possess indicates that similar phenomena occur also in other tropical rivers and estuaries, and even in some of those, such as the Yangtse and its effluents, which lie well outside the Tropics.

(7). Some of the genera in the marine element in the Gangetic fauna are identical with or closely. related to these found in similar situations elsewhere and are of ancient and possibly not of local origin. Others are, however, endemic on the Indian coasts and may have originated in lagoons or estuaries that existed in northern India before the origin of the existing river-systems. 